\title{
The First Discovery of Low-temperature Rhyolite Melts in Cenozoic Long-lived Bazman Volcano, East Iran; Some Problems and Discussion
}

\author{
Alexander Romanko, " , Vsevolod Prokof'ev ${ }^{2}$, Nazim Imamverdiyev ${ }^{3}$, Vladimir Naumov ${ }^{4}$, \\ Pavel Plechov ${ }^{5}$, Anna Balashova ${ }^{6}$, Bahman Rashidi ${ }^{7}$, Mehrdad Hedari ${ }^{8}$, Ilya Vikentev ${ }^{2}$, \\ Alexander Savichev ${ }^{1}$ \\ ${ }^{1}$ Geological Institute, Academy of Sciences, Moscow, Russian Federation \\ ${ }^{2}$ Institute of Geology of Ore Deposits, Academy of Sciences, Moscow, Russian Federation \\ ${ }^{3}$ Geological Faculty, Baku State University, Geological Faculty, Baku, Republic of Azerbaijan \\ ${ }^{4}$ Institute for Geochemistry and Analytical Chemistry, Academy of Sciences, Moscow, Russian Federation \\ ${ }^{5}$ Geological Faculty, Moscow State University, Geological Faculty, Moscow, Russian Federation \\ ${ }^{6}$ Institute of Geochemistry and Petrology, Swiss Federal Institute of Technology, Zurich, Switzerland \\ ${ }^{7}$ Satrap Resources, Perth, Australia \\ ${ }^{8}$ Pars Kani, Tehran, Iran
}

\section{Email address:}

a-romanko@ya.ru (A. Romanko), alx.romanko@gmail.com (A. Romanko),vpr@igem.ru (V. Prokof'ev), inazim17@yahoo.com (N. Imamverdiyev)

${ }^{*}$ Corresponding author

\section{To cite this article:}

Alexander Romanko, Vsevolod Prokof'ev, Nazim Imamverdiyev, Vladimir Naumov, Pavel Plechov, Anna Balashova, Bahman Rashidi, Mehrdad Hedari, Ilya Vikentev, Alexander Savichev. The First Discovery of Low-temperature Rhyolite Melts in Cenozoic Long-lived Bazman Volcano, East Iran; Some Problems and Discussion. Earth Sciences. Vol. 8, No. 4, 2019, pp. 81-87.

doi: $10.11648 /$ j.jirse.20190804.12

Received: June 26, 2019; Accepted: November 4, 2019; Published: November 27, 2019

\begin{abstract}
The igneous rocks, some geological specifics, and also the very melt inclusions in Late Cenozoic rhyolites were studied in the long-lived Miocene (N1, ca. $20 \mathrm{Ma}$ ) - Late Quaternary (Q3?) Bazman volcano, eastern Iran. Unusual low temperature (ca. 690o C) silicate melt inclusions in quartz (Qtz) with a High/very High water content (from average 6.9 to 8.2 (up to 9.0 as a limit) wt\% H2O) in the acid rocks were defined by independent methods for the first time. Whole-rock chemistry of the melts studied is similar to ones in subduction-related acid melts from different regions. Rhyolites studied sometimes have higher concentration of ore elements, similar to ones in even basites. Ore inheritance from economic porphyry - PCD (Cu-Au +- Mo) Paleogene (mainly Eocene - Pg2) mineralization and deposits in the region is proposed. Geological anomaly of the whole region is proposed by a complex analysis. This anomaly is maybe responsible for anomalous magmatism due to a known tomography data (since Paleocene (Pg1), as minimum), tectonics, metallogeny (including economic one), and maybe - hydrocarbons (HC, oil - gas) activity.
\end{abstract}

Keywords: Bazman Volcano, Melt Inclusions, Geology, Geochemistry

\section{Introduction}

We present the first data on acid melt inclusions in the rocks, also rocks, and some geological data on Cenozoic long-lived Bazman volcano and its vicinity, eastern Iran. Melt inclusions were studied by several independent methods led by Prof. Prokof'ev or Prokofiev - et al. [11]. General geology of the region studied is further in the text. 


\section{Method}

Mutual study of melt inclusions by several independent methods was lead by Prof. Vsevolod Yu. Prokof'ev (or Prokofiev). Method was describedin his many publications, for example [11] etc. Also, we used data on melt inclusions from Cenozoic rocks of Lesser Caucasus by $\mathrm{N}$. Imamverdiyev [4]. To examine the inclusions, plates $0.3 \mathrm{~mm}$ in thickness polished on both sides were made of the rhyolite samples. The quartz grains contained numerous homogenous glass inclusions from 3 to $50 \mu \mathrm{m}$ in size, distributed uniformly within quartz and being primary. The glass of the inclusions was usually transparent and colorless, sometimes of greenish shade. The thermometric studies were carried out using a muffle heater made by V. Naumov [6]. The inclusions were heated for $30 \mathrm{~min}$ at constant temperatures, then the samples were tempered. Afterward, the tempered melt inclusions were examined visually by microscopy at room temperature. When heated to $560^{\circ} \mathrm{C}$, numerous bubbles appeared within initially homogenous inclusions, which testified to the glass softening and the withdrawal of volatile components. Further heating caused a decrease in the number of bubbles owing to the dissolution of volatile matter in the glass and to the increase of the glass volume under heating. The bubbles disappeared completely after tempering at $700^{\circ} \mathrm{C}$, and the inclusions became homogenous. The temperature of capture of these inclusions may be evaluated as $680^{\circ} \mathrm{C}$. Melt inclusions (including fully glasseous ones) were examined by electron and ion microprobes. Our special thanks to N. Kononkova for analyzing of silicate glass at Cameca SX 100 electron microprobe under $15 \mathrm{kV}$ power, $30 \mathrm{nA}$ current, and also, $12 \times 12$ and $5 \times 5$ micrometers scanning at Institute of Geochemistry and Analytical Chemistry (this method was described by V. Naumov and V. Prokof'ev in [6] and [11]; also, later in [20]. The minimal concentration for analysis is $0.1 \mathrm{wt} \%$, standard deviation is equal or less than $10 \%$ (table 1 ),

\section{Result}

Main results of our study will be down after geological notes.

Outline of geology.

Long-lived Cenozoic (ca. $20 \mathrm{Ma}-0.040 \mathrm{Ma}$ or N1-Q) Bazman stratovolcano (further in a text - simply Bazman volcano or Bazman), $28007^{\prime} \mathrm{N}$ and 60000 ' $\mathrm{E}$, ca $3.490 \mathrm{~m}$ high (ca. 11500 feet), prominence (relation to the lowest vicinity topography) - ca $2.4 \mathrm{~km} \mathrm{-} \mathrm{is} \mathrm{located} \mathrm{in} \mathrm{non-}$ populated desert in the SE Iran, in Urumieh-Dokhtar or Sahand-Bazman or Central Iranian belt with a long more than $1700 \mathrm{~km}$ (up to $1900 \mathrm{~km}$, figure 1.). This belt extends from northwest (NW) to southeast (SE) and is accompanied by Cenozoic rocks including intrusions [1, 2, 4, 14, 16, 17, 19].

This belt is a result of Cenozoic subduction of oceanic crust beneath the Central Iranian block [7, 8, 13, 14]. Very important economic $\mathrm{Cu}-\mathrm{Au}(+-\mathrm{Mo}, \mathrm{Re})$ porphyry deposits of large region directly deal with Cenozoic (mainly Pg3-N1) magmatism. Epithermal mineralization and the very important world class deposit/s/ with similar elements relate to younger Neogene-Quaternary (N-Q) rocks [2, 13, 18, 19]

Bazman is a rather dormant volcano than active, despite fumaroles were reported. No historic eruptions of Bazman are known and no volcanic risk is proposed here. He is quieter versus younger Taftan volcano (ca $4 \mathrm{~km}$ high, is located ca. $125 \mathrm{~km}$ to $\mathrm{NE}$ from Bazman volcano). Topography of Bazman is surely not so young comparing to fresh one of Taftan. Data about the second - lesser top of Bazman (top N 2), about $3 \mathrm{~km}$ high, NE from the main top are under discussion. Analysis of Bazman area (since Paleogene $(\mathrm{Pg})$ ? calc-alkaline granitoids till Quaternary again calc-alkaline volcanites) concludes long-lived volcanicplutonic association here.

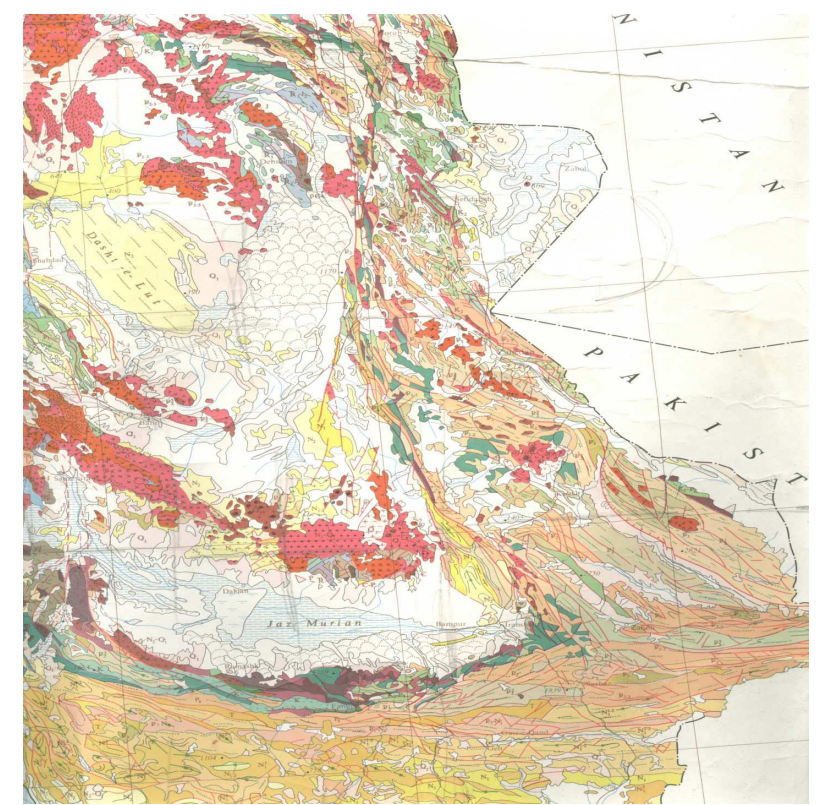

Figure 1. General position of Bazman (in known Lut block) and Taftan volcanoes in south-east Iran, bordering with Pakistan. Bazman volcanoplutonic massif and the very Bazman volcano are to the north of seen Jaz Murian depression (blue), red colors, down of figure. From Geological map of south-east Iran, scale 1: 2500000.

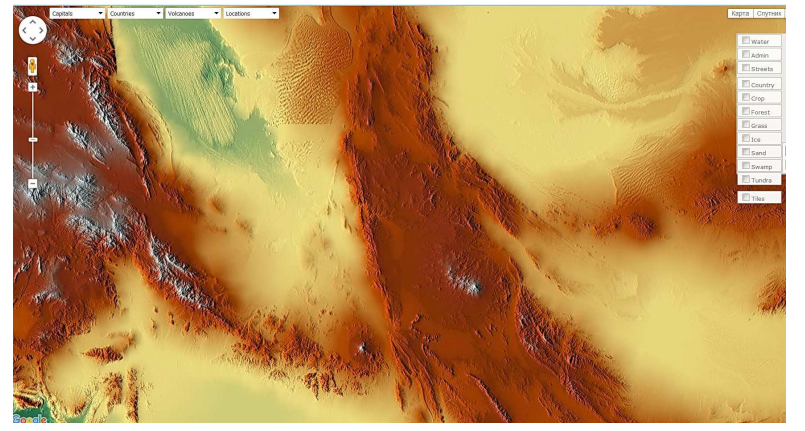

Figure 2. Cenozoic Bazman (ca $3.49 \mathrm{~km}$ high, diameter of crater is about $0.5 \mathrm{~km})$ and Taftan $(4.021 \mathrm{~km}$ high) volcanoes, distinct white points (with snow) - down of figure. Nearly $125 \mathrm{~km}$ between them. Soltan volcano in Pakistan (ca $3 \mathrm{~km}$ high), north-east from Taftan is without snow. Google satellite image.

\section{DATA ON MELT INCLUSIONS AND ROCKS}

Study of melt inclusions in the region was lead by Prof. V. 
Prokof'ev or Prokofiev. Data on melt inclusions from Cenozoic rocks of Lesser Caucasus by N. Imamverdiyev [4, 5] were also used. Some similarities in behavior of melt inclusions from these regions were stressed. Role of alkalinities is higher in melt inclusions of Lesser Caucasus, that in agreement with its magmatism.

Melt inclusions were discovered in quartz of rhyolites R-82, ca $2 \mathrm{~km}$ east of Bazman volcano top (figures 3-6; andesite for comparing-figure 7.). Our special thanks to N. Kononkova for analyzing of glass at Cameca SX 100 electron microprobe under $15 \mathrm{kV}$ power, $30 \mathrm{nA}$ current, and also, $12 \times 12$ and $5 \times 5$ micrometers scanning at Institute of Geochemistry and Analytical Chemistry, Moscow (this methodic was described in: Naumov, 1969; Prokof'ev et al., 2000). The minimal concentration for analysis is $0.1 \mathrm{wt} \%$, standard deviation is equal or less than $10 \%$ (tables 1-3, figure 8).

Seven (7) glasses from melt inclusions in Quartz of rhyolites were analyzed. The average composition of them (wt\%; $\mathrm{S}$ and $\mathrm{Cl}-$ in $\mathrm{ppm}$ ) is as follows (spider-diagram for melt inclusions is in figure 8):

$\mathrm{SiO}_{2}=72.58 \mathrm{wt} \%$

$\mathrm{TiO}_{2}=0.10$

$\mathrm{Al}_{2} \mathrm{O}_{3}=11.24$

$\mathrm{FeO} \mathrm{t}=0.70$

$\mathrm{MnO}=0.05$

$\mathrm{MgO}=0.12$

$\mathrm{CaO}=0.74$

$\mathrm{Na}_{2} \mathrm{O}=2.40$

$\mathrm{K}_{2} \mathrm{O}=3.62$

$\mathrm{P}_{2} \mathrm{O}_{5}=0.07$

$\mathrm{Cl}=0.14 \mathrm{ppm}$

$\mathrm{S}=0.02 \mathrm{ppm}$

$\mathrm{K}_{2} \mathrm{O} / \mathrm{Na}_{2} \mathrm{O}=1.5$.

Average sum of components is $91.77 \mathrm{wt} \%$ that means possible ca $8.2 \mathrm{wt} \%$ of water $\left(\mathrm{H}_{2} \mathrm{O}\right)$ in the melt while maximal water content could be up to high number - $9 \mathrm{wt} \%$. Also, Horiba Raman spectroscopy from Moscow State University shows obvious peak of water in glass of melt inclusions. $6.4 \mathrm{wt} \%$ average value of water was estimated while maximal one is up to $7.7 \mathrm{wt} \%$.

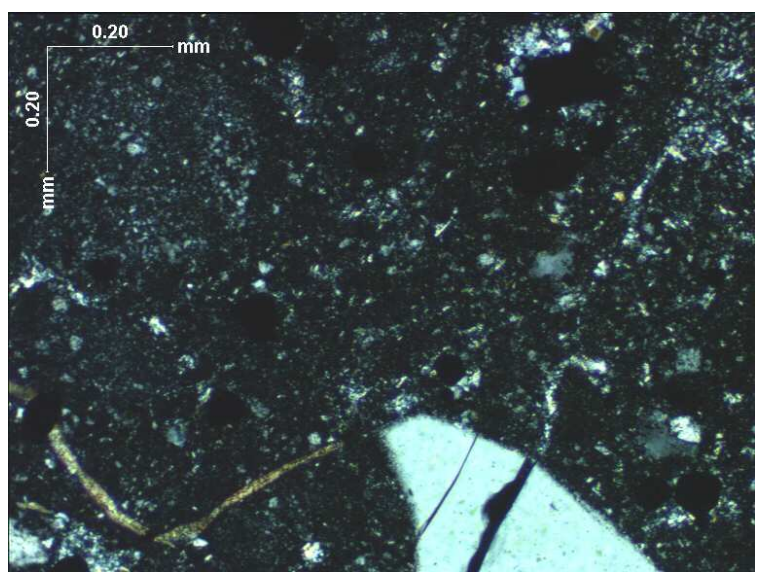

Figure 3. Thin section in CPL (cross-polarized light or $X$ - as symbol). R-82 sample, Calc-alkaline rhyolite. Bazman stratoVolcano. Light Quartz - down of thin section.

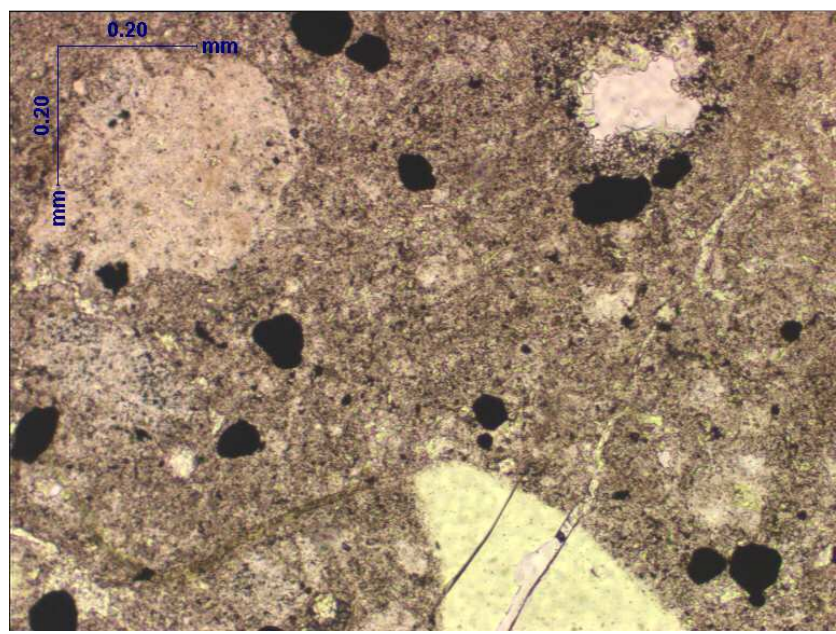

Figure 4. Thin section in PPL (plane-polarized light or II - as symbol). R-82 sample, calk-alkaline rhyolite. Bazman stratoVolcano. Quartz - down of thin section. Dark grains - ore minerals (magnetite is proposed etc.).

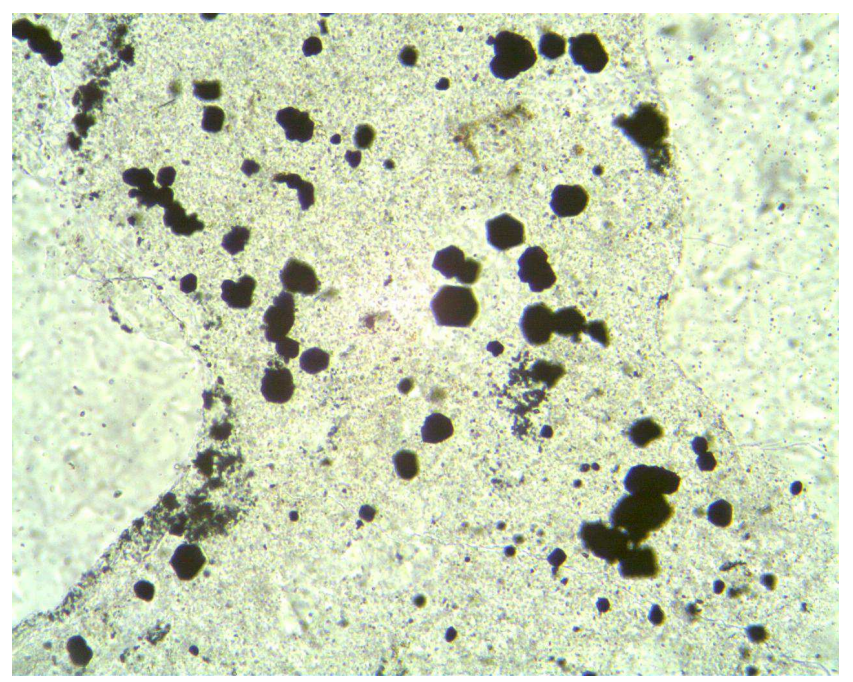

Figure 5. Thin section in PPL (plane-polarized light). R-82-6 sample, calkalkaline rhyolite. Bazman volcano. Dark grains - ore minerals (magnetite is proposed etc.). $\mathrm{Fe} 2 \mathrm{O} 3$ total $=7.81 \mathrm{wt} \%, \mathrm{Cu}=70, \mathrm{Zn}=170, \mathrm{~Pb}=20$, and $\mathrm{Ni}$ $=20$ ppm in some samples.

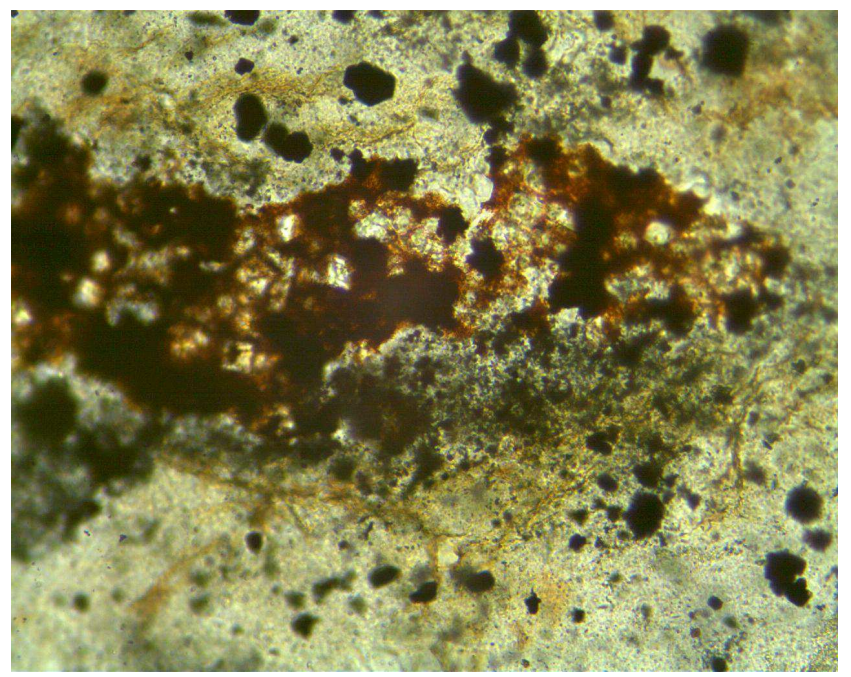

Figure 6. Thin section in CPL. R-82-7 sample, calk-alkaline rhyolite. Bazman volcano. Dark grains - ore minerals. 


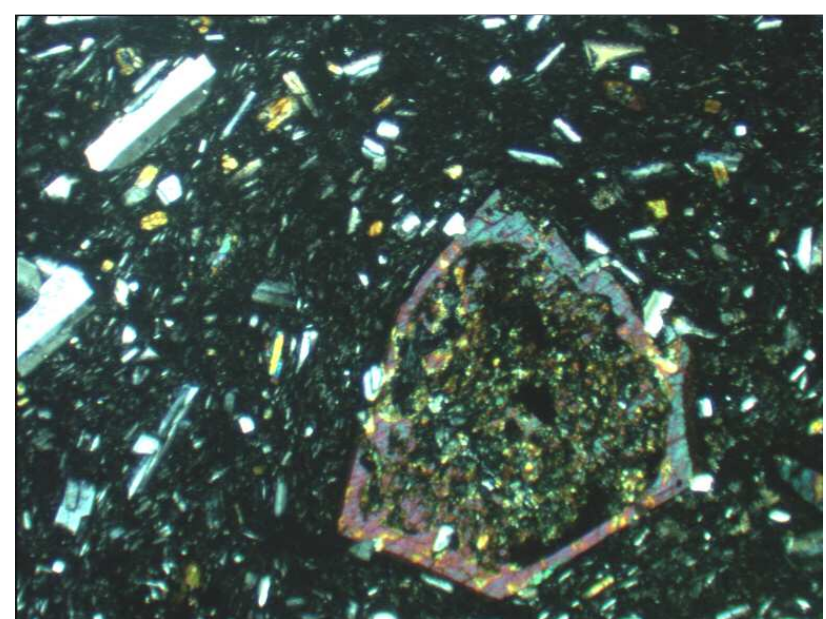

Figure 7. Thin section in CPL (cross-polarized light), R-25 sample, calkalkaline andesite with a porphyry texture (for comparison), Bazman volcano (Romanko et al., 2000, 2005 etc.). Pyroxene with a rim, plagioclase (white), and groundmass.

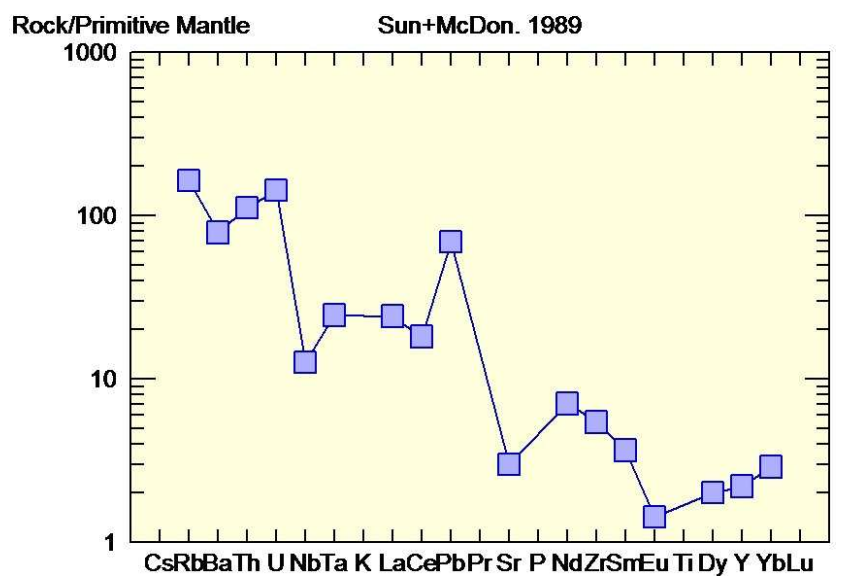

Figure 8. Spider-diagram for glass from melt inclusions in Quartz of rhyolites, Bazman volcano. Note for subduction-related non-flat pattern with $\mathrm{Nb}$, Eu-minimum etc. Also, we see Sr-deficit versus a positive Sr-anomaly in adjacent intraplate $N$ - $Q$ rocks of this large region.

Table 1. Major elements (wt.\%); Cl and S (ppm) in glasses from melt inclusions in Quartz (Qtz) from rhyolites.

\begin{tabular}{|c|c|c|c|c|c|c|c|c|c|}
\hline \multirow{2}{*}{ Component } & \multicolumn{8}{|c|}{ Inclusions, number (1-8) } & \multirow{2}{*}{$\begin{array}{l}\text { Average, } \\
\mathbf{N}=\mathbf{8}\end{array}$} \\
\hline & 1 & 2 & 3 & 4 & 5 & 6 & 7 & 8 & \\
\hline $\mathrm{SiO}_{2}$ & 72.7 & 72.78 & 72.59 & 74.5 & 71.44 & 71.96 & 72.03 & 72.61 & 72.58 \\
\hline $\mathrm{TiO}_{2}$ & 0.10 & 0.14 & 0.14 & 0.10 & 0.07 & 0.09 & 0.13 & 0.06 & 0.10 \\
\hline $\mathrm{Al}_{2} \mathrm{O}_{3}$ & 10.88 & 11.39 & 11.40 & 11.55 & 11.1 & 11.17 & 11.12 & 11.31 & 11.24 \\
\hline $\mathrm{FeO}$ & 0.68 & 0.75 & 0.71 & 0.72 & 0.71 & 0.62 & 0.72 & 0.72 & 0.70 \\
\hline $\mathrm{MnO}$ & 0.05 & 0.07 & 0.05 & 0.08 & 0.06 & 0 & 0.07 & 0 & 0.05 \\
\hline $\mathrm{MgO}$ & 0.08 & 0.12 & 0.12 & 0.12 & 0.13 & 0.16 & 0.13 & 0.13 & 0.12 \\
\hline $\mathrm{CaO}$ & 0.68 & 0.74 & 0.72 & 0.75 & 0.77 & 0.74 & 0.79 & 0.71 & 0.74 \\
\hline $\mathrm{Na}_{2} \mathrm{O}$ & 2.49 & 2.63 & 2.22 & 0.7 & 2.64 & 2.78 & 2.88 & 2.83 & 2.40 \\
\hline $\mathrm{K}_{2} \mathrm{O}$ & 3.69 & 3.69 & 3.74 & 3.12 & 3.57 & 3.7 & 3.71 & 3.75 & 3.62 \\
\hline $\mathrm{P}_{2} \mathrm{O}_{5}$ & 0.04 & 0.02 & 0.03 & 0 & 0.04 & 0.14 & 0.15 & 0.12 & 0.07 \\
\hline $\mathrm{Cl}$ & 0.11 & 0.13 & 0.12 & 0.12 & 0.16 & 0.13 & 0.15 & 0.16 & 0.14 \\
\hline S & 0.02 & 0.04 & 0.03 & 0.01 & 0.01 & 0.03 & 0.01 & 0.02 & 0.02 \\
\hline Sum & 91.52 & 92.50 & 91.87 & 91.77 & 90.70 & 91.52 & 91.89 & 92.42 & 91.77 \\
\hline Raster, m-6 & $12 \times 12$ & $12 \times 12$ & $20 \times 20$ & $5 \times 5$ & $12 \times 12$ & $12 \times 12$ & $12 \times 12$ & $12 \times 12$ & - \\
\hline
\end{tabular}

Table 2. Water (wt\%), F, and trace elements (ppm) in glasses of melt inclusions in Quartz (Qtz) from rhyolites.

\begin{tabular}{|c|c|c|c|c|c|c|}
\hline $\mathbf{N}$ & 1 & 2 & 3 & 4 & 5 & A varar $\mathrm{N}=5$ \\
\hline Component & Inclusion 1 & Inclusion 5 & Inclusion 6 & Inclusion 7 & Inclusion 8 & Average, $N=5$ \\
\hline $\mathrm{H}_{2} \mathrm{O}$ & 5.25 & 5.07 & 4.72 & 5.15 & 4.00 & 4.84 \\
\hline $\mathrm{F}$ & 129 & 154 & 108 & 125 & 108 & 124.8 \\
\hline $\mathrm{Li}$ & 19.5 & 22.9 & 28.9 & 43.3 & 217 & 66.32 \\
\hline $\mathrm{Be}$ & 1.21 & 1.16 & 1.12 & 1.23 & 0.73 & 1.09 \\
\hline B & 52.8 & 50.5 & 48.4 & 52.4 & 30.9 & 47.0 \\
\hline V & 7.93 & 7.51 & 7.92 & 9.42 & 8.32 & 8.22 \\
\hline $\mathrm{Cr}$ & 1.15 & 0.87 & 1.01 & 1.23 & 1.57 & 1.17 \\
\hline $\mathrm{Cu}$ & 33.0 & 18.2 & 22.1 & 34.0 & 33.3 & 28.1 \\
\hline $\mathrm{Rb}$ & 106 & 98 & 102 & 109 & 105 & 104 \\
\hline $\mathrm{Sr}$ & 64.1 & 60.7 & 64.4 & 64.0 & 61.0 & 62.8 \\
\hline Y & 10.6 & 9.44 & 10.1 & 10.3 & 9.23 & 9.93 \\
\hline $\mathrm{Zr}$ & 60.4 & 66.4 & 60.2 & 60.9 & 57.7 & 61.1 \\
\hline $\mathrm{Nb}$ & 9.12 & 9.99 & 9.16 & 9.51 & 8.34 & 9.22 \\
\hline $\mathrm{Ta}$ & 1.00 & 0.96 & 0.98 & 1.18 & 0.99 & 1.02 \\
\hline $\mathrm{Ba}$ & 547 & 550 & 549 & 575 & 535 & 551.2 \\
\hline $\mathrm{La}$ & 17.0 & 15.6 & 16.9 & 17.4 & 15.9 & 16.6 \\
\hline $\mathrm{Ce}$ & 32.0 & 31.6 & 33.4 & 33.3 & 30.5 & 32.2 \\
\hline $\operatorname{Pr}$ & 2.92 & 2.54 & 2.69 & 2.96 & 2.69 & 2.76 \\
\hline $\mathrm{Nd}$ & 10.4 & 8.91 & 9.92 & 10.3 & 8.34 & 9.57 \\
\hline $\mathrm{Sm}$ & 1.58 & 1.59 & 1.72 & 1.68 & 1.55 & 1.62 \\
\hline $\mathrm{Eu}$ & 0.06 & 0.31 & 0.24 & 0.36 & 0.21 & 0.24 \\
\hline $\mathrm{Gd}$ & 1.38 & 1.51 & 2.14 & 1.21 & 1.51 & 1.55 \\
\hline Dy & 1.47 & 1.48 & 1.47 & 1.54 & 1.44 & 1.48 \\
\hline
\end{tabular}




\begin{tabular}{|c|c|c|c|c|c|c|}
\hline $\mathbf{N}$ & 1 & 2 & 3 & 4 & 5 & \\
\hline Component & Inclusion 1 & Inclusion 5 & Inclusion 6 & Inclusion 7 & Inclusion 8 & Average, $N=5$ \\
\hline $\mathrm{Er}$ & 1.50 & 1.15 & 1.17 & 1.52 & 1.11 & 1.29 \\
\hline $\mathrm{Yb}$ & 1.40 & 1.35 & 1.45 & 1.56 & 1.41 & 1.43 \\
\hline $\mathrm{Lu}$ & 0.23 & 0.21 & 0.23 & 0.25 & 0.21 & 0.23 \\
\hline $\mathrm{Hf}$ & 2.02 & 2.34 & 1.69 & 2.09 & 2.03 & 2.03 \\
\hline $\mathrm{Pb}$ & 4.64 & 4.09 & 4.65 & 6.10 & 5.06 & 4.91 \\
\hline Th & 10.0 & 9.00 & 9.45 & 9.76 & 9.08 & 9.46 \\
\hline $\mathrm{U}$ & 3.11 & 3.08 & 2.89 & 3.16 & 2.93 & 3.03 \\
\hline $\mathrm{Th} / \mathrm{U}$ & 3.2 & 2.9 & 3.3 & 3.1 & 3.1 & 3.1 \\
\hline $\mathrm{La} / \mathrm{Yb}$ & 12 & 12 & 12 & 11 & 11 & 11.6 \\
\hline$(\mathrm{La} / \mathrm{Yb}) \mathrm{N}$ & 8.1 & 7.7 & 7.8 & 7.5 & 7.5 & 7.8 \\
\hline $\mathrm{Eu} / \mathrm{Eu}^{*}$ & 0.12 & 0.62 & 0.38 & 0.78 & 0.42 & 0.47 \\
\hline
\end{tabular}

Notes. Inclusion numbers $(1,5-8)$ are the same as in previous Table 1.

Table 3. Whole-rock chemistry for acid rocks, E. Bazman volcano.

\begin{tabular}{|c|c|c|}
\hline Component & R-82, late leuco-rhyolite, $\mathrm{T}=690 \mathrm{CC}$, up to $8.2(9.0) \mathrm{wt} . \% \mathrm{H} 2 \mathrm{O}$ for rhyolites & R-82-5, rhyolite, XRF method \\
\hline $\mathrm{SiO}_{2}$ & 85.02 (and 86.00 ) & - \\
\hline $\mathrm{TiO}_{2}$ & 0.60 & 1.12 \\
\hline $\mathrm{Al}_{2} \mathrm{O}_{3}$ & 4.00 & - \\
\hline $\mathrm{Fe}_{2} \mathrm{O}_{3}$ & 3.21 & - \\
\hline Fe2O3total & - & 4.04 (and 7.8) \\
\hline $\mathrm{FeO}$ & 1.10 & - \\
\hline $\mathrm{MnO}$ & 0.02 & 0.12 \\
\hline $\mathrm{MgO}$ & 0.52 & - \\
\hline $\mathrm{CaO}$ & 0.29 & 0.99 \\
\hline $\mathrm{Na}_{2} \mathrm{O}$ & 0.28 & - \\
\hline $\mathrm{K}_{2} \mathrm{O}$ & 0.21 & 4.35 \\
\hline $\mathrm{P}_{2} \mathrm{O}_{5}$ & 0.09 & - \\
\hline $\mathrm{Rb}$ & 10 & 93 \\
\hline $\mathrm{Ba}$ & 390 & 781 \\
\hline $\mathrm{Sr}$ & 440 & 478 \\
\hline $\mathrm{Ni}$ & 10 & 20 \\
\hline Co & 4 & - \\
\hline $\mathrm{Cr}$ & 11 & less than $64 \mathrm{Cr} 2 \mathrm{O} 3$ \\
\hline V & 55 & - \\
\hline $\mathrm{Cu}$ & 17 & 70 \\
\hline $\mathrm{Zn}$ & 8 & 170 \\
\hline $\mathrm{Pb}$ & 20 & Less than 10 \\
\hline $\mathrm{Zr}$ & 136 & 516 \\
\hline Y & 13 & 36 \\
\hline $\mathrm{Nb}$ & 6 & - \\
\hline $\mathrm{Sc}$ & 6.5 & - \\
\hline Th & 1 & - \\
\hline $\mathrm{U}$ & 3 & - \\
\hline $\mathrm{La}$ & 15 & 56 \\
\hline $\mathrm{Ce}$ & 28 & 104 \\
\hline $\mathrm{K} / \mathrm{Rb}$ & 230 & 370 \\
\hline
\end{tabular}

Notes. Water content in these rhyolites - up to $8-9 \mathrm{wt} \%$ (average $=6.9 \mathrm{wt} \%$ ). $\mathrm{K}$ and Rb have positive correlation for rock glasses. Bold $=$ higher content of $\mathrm{Cu}$ and Zn, similar to those in some world basalts (Kovalenko and Yarmoluk, Ed., 1983; Luchitsky, 1985; Marakushev, 1988; Shilov, 1999; Naumov et al., 2010 etc.).

\section{Discussion}

Unfortunately, general geology, tectonics, and magmatism of this region is not yet clear. Evolution of magmatism in volcanoes, uncluding Soltan in Pakistan is of great importance, surely. Role of delamination - fairly far from Turkey and African superPlume is not quite clear.

Some main preliminary conclusions on melt inclusions are as follows:

1. Unusual High-water melt inclusions were firstly discovered by independent methods in long-lived
Bazman volcano rhyolites (samples R-82). High $\mathrm{H} 2 \mathrm{O}$ content is from $6.9 \mathrm{wt} \%$ up to maybe $9 \mathrm{wt} \%$. T crystallization is fairly high for the very late (maybe the very last) Quaternary (Q3 ?) rhyolites and leucorhyolites of Bazman volcano $-690 \mathrm{oC}$. Also, $\mathrm{T}$ is very high 9 (up to $1220 \mathrm{oC}$ ) for Quaternary dacites (samples R-75) of Bazman area.

2. Melt inclusions are not typical for Neogene? intraplate rocks in the region studied and also for Eocene (Pg2) shoshonites - latites of Abbas-Abad Cu-mining area, NE Iran (samples of M. Heidari). Similarities for melt inclusions in Cenozoic rocks of east Iran and Lesser 
Caucasus were found.

3. Acid Quaternary (?) rocks have higher concentration of ore elements, similar to ones in even some basalts. Ore inheritance from important economic porphyry, $\mathrm{Cu}-\mathrm{Au}$ +- Mo (+- Re?) Eocene - Miocene (Pg2 - N1) mineralization in this region is proposed.

\section{Conclusion}

We propose next conclusions as follows:

i. Unusual High-water melt inclusions were discovered by independent methods in acid rocks of long-lived Cenozoic Bazman volcano for the first time. $\mathrm{H} 2 \mathrm{O}$ high content is from average $6.9 \mathrm{wt} \%$ up to 8.2-(9) wt $\%$.

ii. These acid Quaternary? rocks sometimes have higher concentration of ore elements, similar to ones in even basites. Ore inheritance from important economic porphyry (Cu-Au +- Mo) Paleogene (mainly Pg2) mineralization in the region is proposed.

iii. Thermal anomaly of the whole region is proposed by a complex analysis. This thermal anomaly is responsible for anomalous magmatism (since Paleocene (Pg1), as minimum), tectonics, metalogeny (including economic one), and maybe hydrocarbons ( $\mathrm{HC}, \mathrm{OG}$, oil - gas) activity. Hydrocarbons need really a fairly thermal regime and higher permeability by a theory. Also, there are data about physical anomaly in this region.

iv. Common magmatic source for the Cenozoic Bazman Taftan - Soltan volcanoes is proposed here again. Long live of Bazman volcano (volcanic-plutonic association) relates to proximity of lithosphere root delamination and also - African superplume, as proposed. In Pamir in Neogene ? only deep rare alkaline intrusions (similar to lamproites) could be realized due to strong collision versus Neogene - Quaternary volcanites in Turkey- Iran - Pakistan etc.

v. Active volcanoes of Caucasus, Armenia, Turkey and also, (+- Iran?) exist due to anomaly of this large region.

\section{Recommendations}

Surely, more analytics (including whole rock-chemistry) is very welcome. The whole distribution of melt inclusions is not clear. We are hope that geology, magmatism and melt inclusions study will be improved etc.

\section{Acknowledgements}

We are especially grateful to outstanding regional trio: Dr. A. Houshmanzadeh, Dr. M. A. A. Nogole-Sadat $\dagger$, and Dr. E. Romanko $†$ for a leadership during field works in E. Iran and big help; also special thanks to N. Kononkova (analysis of melt glass at the Vernadsky Institute of Geochemistry and Analytical Chemistry, Academy of Sciences, Moscow); also - to M. Hosseini, V. Volkov†, L. N. V. Romanko $\dagger$ and many others for discussion and help.

The research was supported by the State program no.
0135-2018-0034 (Geological Institute, Russian Acad. Sci.; N. Chamov).

\section{References}

[1] Bull A. L., McNamara A. K., Ritsema J., 2009. Plume clusters and thermochemical piles. Earth Planet. Sci. Lett. Vol. 278, pp. 152-162.

[2] Daliran F., Paar W. H., Neubauer F., and Rashidi B., 2005. New discovery of epithermal gold at Chahnali prospect, Bazman volcano, SE-Iran. Society for Geology Applied to Mineral Deposits Biennial SGA Meeting, 8th, Beijing, China, 18-21 August 2005. Proceedings. V. 2. P. 917-919.

[3] Di Muro A., Villemant B., Montagnac G., Scaillet B., Reynard B., 2006. Quantification of water content and speciation in natural silicic glasses (phonolite, dacite, rhyolite) by confocal micro Raman spectrometry. Geochimica et Cosmochimica Acta. 70. P. 2868-2884.

[4] Imamverdiyev, N. A., 2000. Geochemistry of Late Cenozoic Volcanic Complexes in the Lesser Caucasus. Nafta Press, Baku, 192 p. In Russian.

[5] Imamverdiyev, N. A., 2003. Rare earth element geochemistry of Late Cenozoic volcanic series in the Lesser Caucasus. Geochem. Int. 41 (4), 379-394.

[6] Naumov V. B., Kovalenko V. I., Dorofeeva V. A. et al., 2010. Mean composition of magmatic melts in main geodynamic settings by melt inclusions study in minerals and glasses. Geochemistry Internartional. N 12. P. 1266-1288. In Russian.

[7] Keskin M., 2005. Domal uplift and volcanism in a collision zone without a mantle plume: Evidence from Eastern Anatolia. http://www.mantleplumes.ord/Anatolia.html.

[8] Kopp C., Fruehn J., Flueh E. R., Reichert C., Kukowski N., Bialas J., and Klaeschen D., 2000. Structure of the Makran subduction zone from wideangle and reflection seismic data. Tectonophysics. V. 329. P. 171-191.

[9] Luchitsky I. V., 1985. Palaevolcanology. M: Nauka. 235 p. In Russian.

[10] Marakushev A. A., 1988. Petrology. M: Nauka. 211. In Russian.

[11] Prokof'ev V. Yu., Bortnikov N. S., Zorina L. D., Kulikova Z. I., Matel N. L., 2000. The Darasun intrusive-related goldpolimetallic deposit, EasternTransbaikalia, Russia: Petrochemical, melt and fluid inclusion, REE and stable isotope $(\mathrm{O}, \mathrm{C}$, and $\mathrm{S})$ studies Applid Mineralogy. Rammlmair et al. (eds). Balkema, Rottertdam, Brookfield. P. 399-402.

[12] Regard V., Hatzfeld D., Molinaro M., Aubourg C., Bayer R., Bellier O., Yaminifard F., Peyret M., and Abbassi M., 2010. The transition between Makran subduction and the Zagros collision: Recent advances in its structure and active deformation. Geological Society of London, Special Publication. V. 330. P. 41-64.

[13] Richards J. P., Spell T., Rameh E., Razique A., and Flectcher T., 2012. High $\mathrm{Sr} / \mathrm{Y}$ magmas reflect arc maturity, high magmatic water content, and porphyry $\mathrm{Cu} \pm \mathrm{Mo} \pm \mathrm{Au}$ potential: Examples from the Tethyan arcs of central and eastern Iran and western Pakistan. Economic Geology. V. 107. P. 295-332. 
[14] Romanko A., Imamverdiyev N. A., Prokof'ev V., Vikentev I., Rashidi B., Savichev A., Heidari M., 2018. Some new and previous materials on Alpine magmatism, tectonics, melt and fluid inclusions, and metallogeny in Eastern Iran. International Journal of Mining Science. V. 4. Issue 1. P. 11-28.

[15] Romanko A., 2005. New data on Cenozoic subalkaline intraplate rocks the East Iran. Reports of the Russian Academy of Sciences. Earth Sciences Section. V 404, N 7, pp. 510-513.

[16] Romanko E., Kokorin Y.., Krivyakin B. et al., 1984. Outline of metallogeny of Anarak Area (Central Iran). Ministry of mines and metals. Geological Survey of Iran. Rep. 21, Tehran. Technoexport, $136 \mathrm{p}$.

[17] Romanko E., Romanko A., Houshmand-zadeh A., NogoleSadat M. A. A., Meskhi A. Some new data on Cenozoic magmatism and mineralization in eastern Iran. 31 IGC. Abstracts. Brasil. 2000.
[18] Romanko E., Voinkov D., Houshmandzadeh A. et al., 2000. Characteristic features of ore mineralization in the SistanBaluchestan Province, SE Iran: evidence from fluid inclusions data. International conference on geology of Mediterranean belt. Absracts. Beograd.

[19] Sholeh A., Rastad E., David Huston D., Gemmell J. B., and Taylor R. D., 2016. The Chahnaly Low-Sulfidation Epithermal Gold Deposit, Western Makran Volcanic Arc, Southeast Iran. Economic Geology. V. 111. P. 619-639.

[20] Sobolev, A. V. 1996. Melt inclusions in minerals as a source of principle petrological information. Petrology, 4 (3): 209220. 